\title{
An attempt to evaluate some personality characteristics of Wroclaw high school graduates of different pubescence age
}

\author{
Ewa Kolasa', Wioleta Umławska ${ }^{1}$, Ewa Olszewska ${ }^{2}$ \\ ${ }^{1}$ Department of Anthropology, University of Wrocław, Kuźnicza 35, \\ 50-138 Wrocław, Poland, E-mail: kolasa@antropo.uni.wroc.pl \\ ${ }^{2}$ Specjalistyczny Zespół Opieki Zdrowotnej nad Matką i Dzieckiem, \\ Krakowska 28, 50-425 Wrocław, Poland
}

\begin{abstract}
An attempt was made to establish the correlation between the time of reaching sexual maturity and the level of psychical development. The material consisted of data obtained from schoolgirls of final classes of 6 secondary schools. In a questionnaire, the girls provided retrospective data concerning the age of menarche, and replied to questions being the basis for sexual maturity evaluation.
\end{abstract}

KEY WORDS pubescence, personality, menarche, sexual maturity

Prz. Antropol. - Anthropol. Rev. (2000), vol. 63, pp. 73-84, Tables 12. ISBN 83-8696960-1, ISSN 0033-2003

\section{Introduction}

Psychology is a field in which a physical anthropologist does not engage readily, mainly because of its specific research method demanding specialized knowledge. We do not hesitate to reach for subjects within the realm of sociology, theory of physical education and sport or even medicine, but we do (paradoxically) with regard to the field which deals with the personality sphere, inseparable from the physical one, that is human psyche. Those spheres are known to interact during the whole human life. Therefore, the processes of physical and psychical pubescence must take place not "beside each other" but in a mutually related way. This results not only from close functional relations between the central nervous system and the endocrine system. Apart from that direct dependence, one must also consider secondary mutual influences of both spheres.

In spite of that, anthropologists rarely undertake the research concerning the boundary of psychology and human biology. It seems understandable since this research subject, that is individual human development, requires different methods from a psychologist and a biologist, which undoubtedly makes co-operation 
difficult. If an anthropologist has relatively objective and easily perceptible standards enabling him to establish realistic development norms, a psychologist, out of necessity, bases on personality maturation symptoms that are far less distinct and perceptible and are also so complex and individually differentiated that establishing development standards has a rather theoretical value [BADURAMADEJ 1981; OBUCHOWSKA 1983]. As stated by CHŁOPKIEWICZ [1987], the moment of reaching psychical maturity cannot be univocally determined because, in its assessment, what testifies to the acquired level of structural-functional development is hard to separate from its specific, individual direction. The employed criteria of maturity, such as (among others) socialization, creative attitude, ease of entering interpersonal relations and self-acceptance are not really symptoms of maturity but rather of mental sanity or even more exactly - of adaptation. Therefore, reaching psychical maturity equals attaining adaptation. On the other hand, individual differences of psycho-physical construction and social conditions are sufficient for the individual who reached all stages of physical development not to demonstrate the characteristics mentioned above or even to demonstrate quite the opposite ones (pathological personality in extreme cases). REYKOWSKI [1977] expressed it very accurately many years ago stating that "development is a process unlimited in its individual properties", and WIŚNIEWSKI [1998] also said quite recently that human personality "does not exist but becomes". Therefore, it is difficult to quote research papers aiming at establishing direct relations between the time of reaching sexual and psychical maturity.
All these limitations and difficulties, however, do not concern the problem of influence of some psychical factors on the course of sexual pubescence and they did not hinder the examination of such relations proving that some disorders of family life might accelerate the puberty process [HULANICKA 1986; SURBEY 1990; ŁUCZAK \& ŁASKA-MIERZEJEWSKA 1990; MOFFIT et al. 1992; ŁUCZAK 1994]. The situation is more difficult when one has to seek the reverse interdependence, that is the influence of biological development rate on the evolution of the psychical part of personality. However, there were attempts to set standards also in this field [Z̈UKOWSKI 1966; RÓŻYCKA 1968; ZDUNKIEWICZ 1970; STRZYŻEWSKI 1974; ILG et al. 1998; BODZSAR 1999]. Their research usually concerned intellectual competence and intelligence of children (relatively easy to evaluate) in relation to the attained level of somatic development and sexual maturity at a certain age. In his monographic work from 1974 Strzyżewski considered also the level of social adaptation, activity, degree of acceptance by the peer group, and neuroticism of children maturing early and late.

Psychologists, just as anthropologists, are not very interested in the subjects of the discussed interdisciplinary boundary. Even though a psychologist recognizes a significant role of stress in the personality formation, yet - as STRZYŻEWSKI [1974] highlighted - he usually looks for their sources in social and cultural conditions rather than in causes of biological nature. One can mention some publications, however, stating that the great advance or delay in physical development entailing certain dissimilarity in comparison to peers may become the source of stress and 
tension [SPIONEK 1973; OBUCHOWSKA 1983, 1996; HURLOCK 1985; ŻEBROWSKA 1986; CHŁOPKIEWICZ 1987]. These, in turn, might lead to the feeling of inferiority, for which OBUCHOWSKI [1972] suggested the name of the "difference complex".

One of the important results of the hitherto conducted research was demonstrating that the trend of acceleration observed for many tens of years is stronger with regard to physical development than to psychical one, causing a growing disproportion between biological and psycho-social maturity of an individual (JACZEWSKI \& WOYNAROWSKA [1982]; JACZEWSKI [1995]; GADAMSKA et al. [1997] among others). It is in this "perplexity" between the attained level of development in both spheres that psychologists, educators and sociologists see the source of undesirable social phenomena such as: too soon initiation of sexual contacts, instability of equally early contracted marriages, intensive frequency of abortions, unwanted and deserted children, juvenile crime, drug addiction, and finally alcohol and nicotine addiction spreading among younger and younger groups. During recent decades these phenomena have grown stronger all over the world (including Poland) and particularly in the highly developed countries.

It is worth pointing out that all the publications mentioned above usually concern the pubescence period or the moment directly afterwards, mainly up to 15 years of age. Yet - as HURLOCK [1985] and other authors say - undesirable attitudes, formed during the deviation period from the average sexual development, still remain when the appropriate maturity level is finally reached. Deviations in the sexual development frequently cause changes that are hard to overcome. One of the reasons is a fact that girls and boys staying behind their peers are usually treated by adults and peers alike according to their physical appearance rather than age, i.e. are treated like small children. Those who outdistance their peers, on the other hand, are confronted with excessive demands. Fighting for position that they deserve in their own opinion, young people form antisocial attitudes. However, the more partner-like approach of adults towards girls and boys of earlier pubescence age, and the more prolonged childish treating of those with delayed pubescence, the stronger the possibility of psychical maturity in the former group and the weaker in the latter one. Besides, undesirable attitudes and behavioral patterns tend rather to remain than to disappear with time and may even get worse. Whether the attitudes characteristic of the pubescence period will influence the future socialization depends, among others, on the time when the sexual puberty took place, how long it lasted and to what degree it is consistent with the age standards [HURLOCK 1965, 1985].

The goal of this research was an attempt to find out whether the psychical consequences mentioned above of an early or late puberty concern and reach the age of 18-19 of girls, when they are physically and "legally" mature.

\section{Materials and methods}

The research was conducted in winter of 1998/99 among 450 students of senior classes of six Wrocław high schools, aged 18 and 19. The material is mostly homogenous due to social origins. Practically all girls live in Wrocław, their parents have higher or high education, 
where a family model with two children prevails. The girls provided the remembered age of first menstruation and filled in an anonymous questionnaire. As we have already mentioned, the moment of complete psychical maturity, so easy to recognize in physical development, cannot be univocally determined. Thus, the questionnaire aimed only at the evaluation of some personality characteristics and the questions were composed basing on the criteria of the maturity level adopted by psychologists [ALLPORT 1970; CHŁOPKIEWICZ 1987; SMOLEŃSKA \& WIECZORKOWSKA 1993; GADAMSKA et al. 1997].

The analysis consisted in comparing the average menarche age of the girls grouped according to different variants of answer to the asked question. The significance of differences was evaluated with the variance analysis and the t-Student test. The strength of relation between an early (up to 12 years of age), medium and late (over 14 years of age) menarche age and the frequency of particular answer variants was evaluated with chi-square criterion.

\section{Analysis}

Arithmetic mean values of the menarche age of respondents amount to 13.02 years of age $(M e=13.00, S D=1.13$, min. 9.17, max. 16.75). The answers given to the remaining questions show certain tendencies (generally consistent with psychologists' observations), yet the menarche age of the respondents does not show any significant differentiation in relation to the provided answers.

The first question was related to the decision concerning the choice of future education and the answers were classified like in Table 1. As stated by GADAMSKA et al. [1997] the ability of making choices and controlling them and the ability of setting oneself distant aims develops during the final stage of maturation, and ALLPORT [1970] talks about the gradual directing towards the chosen aims. We found out that the girls who had long ago (at least during the previous school year) made their decisions, entered pubescence 0.2 of year earlier than those who, until the moment of research or until quite recently, had not made their final decision. The difference does not reach the statistical significance threshold.

Table 1. Age of menarche in girls of different degree of decisiveness concerning choice of further education

\begin{tabular}{lccc}
\hline Further education & $\bar{X}$ & $N$ & $S D$ \\
\hline $\begin{array}{l}\text { does not know } \\
\text { is hesitant and has }\end{array}$ & 12.96 & 8 & 1.43 \\
$\begin{array}{l}\text { made decision recently } \\
\text { has made decision long }\end{array}$ & 13.10 & 247 & 1.12 \\
time ago* & 12.92 & 192 & 1.11 \\
\hline * at least as long ago as previous school year
\end{tabular}

As the answer to the additional question (degree of self-dependence in decision making) demonstrates, the students who made the above decision totally independently entered pubescence somewhat earlier than the ones who admitted that they yielded to suggestions or pressure of somebody else (there were only 19 girls in that group) (Table 2). The difference was 4 months ( 0.32 of year), but it was statistically insignificant. This question was based on the observations proving that both the ability to control decisions [GADAMSKA et

Table 2. Degree of self-dependence in decision making versus age of menarche

\begin{tabular}{lccc}
\hline Decision made & $\bar{X}$ & $N$ & $S D$ \\
\hline indepently & 12.99 & 404 & 1.11 \\
after persuasion & 13.31 & 21 & 1.16 \\
\hline
\end{tabular}


al. 1997], and the aspiration to internal control and the rejection of external control increase with pubescence. According to ALLPORT 1970] "I" self-determines itself, separates and frees itself from external pressures along the development.

Next question concerned the degree of difficulty in entering interpersonal relations with strangers according to personal evaluation of the respondents. This question aimed at evaluating social adaptation which manifests itself in the ease of initiating interpersonal relations characterizing a mature individual [GADAMSKA et al. 1997] and also Kinsey's thesis [after STRZYŻEWSKI 1974] saying that physically-early developed individuals are rather extroverted, and late-developed, introverted. Our results, yet, do not prove this thesis. The answers did not demonstrate any significant dependence on the puberty age but only revealed a rather unexpected tendency: the girls who declared greater ease entered puberty later but the difference is far from statistical significance (Table 3).

Table 3. Degree of difficulty in making friends versus age of menarche

\begin{tabular}{lccc}
\hline Degree of difficulty & $\bar{X}$ & $N$ & $S D$ \\
\hline difficult & 12.80 & 9 & 1.33 \\
fairly difficult & 12.94 & 37 & 1.37 \\
fairly easy & 13.02 & 243 & 1.07 \\
easy & 13.06 & 161 & 1.15 \\
\hline
\end{tabular}

The dependence between the puberty age and the ability of making independent choices (finding a solution) in difficult situations evaluated by self-estimation is presented in Table 4. According to SMOLEŃSKA \& WIECZORKOWSKA [1993] a young person tends with age to describe himself as a person using his own judgment of good and rejecting the pressure of the authorities and peers alike. In our material, the girls saying that they
Table 4. Ability of making choice in difficult situations versus age of menarche

\begin{tabular}{lccc}
\hline Making choice & $\bar{X}$ & $N$ & $S D$ \\
\hline $\begin{array}{l}\text { they avoid it or make } \\
\begin{array}{l}\text { others responsible for } \\
\text { their decision }\end{array}\end{array}$ & 13.25 & 15 & 1.14 \\
$\begin{array}{l}\text { they take into considera- } \\
\text { tion only their own }\end{array}$ & 13.01 & 365 & 1.14 \\
$\begin{array}{l}\text { opinion } \\
\text { they respect others' point } \\
\text { of view }\end{array}$ & 12.97 & 23 & 0.85 \\
\hline
\end{tabular}

use only their own judgment do not differ in puberty age from those (few) who admit taking the others' opinion into consideration while making decision. Those girls, on the other hand, who admit avoiding decision-making in difficult situations in general, and leave it to others, enter puberty 3 months ( 0.28 of year) later; the difference, however, is statistically insignificant (since there were only 15 students of the latter group). According to the representatives of cultural psychoanalysis (Fromm - after CHŁOPKIEWICZ [1987]) "The apex of development denotes freeing positive tendencies from pressures of social disapproval, development of self-respect and individuality".

A question that aimed at revealing the degree of difficulty in expressing personal opinion different from the interlocutor's opinion did not bring expected differentiation (Table 5).

Table 5. Degree of difficulty in presenting one's opinion different from interlocutor's point of view versus age of menarche

\begin{tabular}{lccc}
\hline Degree of difficulty & $\bar{X}$ & $N$ & $S D$ \\
\hline easy & 13.03 & 427 & 1.11 \\
difficult & 12.95 & 22 & 1.34 \\
\hline
\end{tabular}

The answers to the question: which factors determined your personality to the greatest degree? (hereditary factors, parental upbringing or you yourself?) were as shown in Table 6. According to 
Table 6. Replies to question, 'What influenced your personality most?' versus age of menarche

\begin{tabular}{lccc}
\hline Factors & $\bar{X}$ & $N$ & $S D$ \\
\hline hereditary & 13.07 & 81 & 1.12 \\
upbringing & 13.00 & 229 & 1.13 \\
I myself & 12.97 & 105 & 1.17 \\
\hline
\end{tabular}

ALLPORT [1970] responsibility for oneself is a proof of psychical maturity. Those girls who thought that hereditary factors were primarily responsible for their personality ("because I was born like that") entered puberty somewhat later than those who regarded the upbringing factor and self-improvement as more important. But menarche age did not differ significantly.

Self-estimation of psychical maturity was consistent with real varied rate of sexual pubescence in comparison to peers (Table 7) retaining the following gradient: the higher the sense of maturity the earlier the menarche age. The number of girls admitting low self-esteem was small $(\mathrm{N}=15)$, so their delayed puberty, of more than 4 months later, in comparison to peers of the contrary opinion, did not reach the statistical significance level.

Table 7. Self-evaluation of psychic maturity when compared to peers versus age of menarche

\begin{tabular}{lccc}
\hline Self-evaluation of maturity & $\bar{X}$ & $N$ & $S D$ \\
\hline lower & 13.28 & 15 & 1.24 \\
average & 13.07 & 264 & 1.13 \\
higher & 12.93 & 169 & 1.10 \\
\hline
\end{tabular}

Many of the students admitted that they regularly smoked cigarettes (none smoked before puberty). They entered puberty 0.18 year later than non-smokers. The difference, however, was not statistically important (Table 8). This question was asked intuitively basing on the conviction that smoking at school age is a symptom of immaturity and results from the need of adding self-estimation in front of the peer group.
The used chi-square test did not reveal any significant relation between the moment of puberty expressed in three categories of menarche age (early - before 12 years of age, late - after 14 years of age, average all other cases) and different answer variants provided to all the questions.

Table 8. Girls' nicotine addiction versus age of menarche

\begin{tabular}{lccc}
\hline Nicotine addiction & $\bar{X}$ & $N$ & $S D$ \\
\hline smoking girls & 13.14 & 162 & 1.00 \\
non-smoking girls & 12.96 & 288 & 1.18 \\
\hline
\end{tabular}

An honest evaluation of the results required also finding out whether and to what extent the observed tendencies concerning relations between the beginning of pubescence and the development of the analyzed personality characteristics were distorted by different (and yet similar) age of the examined girls (18-19 years of age) and their different social status resulting from their parents' education level. Arithmetic mean values of the calendar age of respondents maturing early and late were compared for this purpose. It appeared that those girls who declared an early menarche were actually younger at the time of study ( 0.12 year younger, $\mathrm{p}<0.01)$ than those declaring a late menarche (Table 9). Thus, it was not age that caused more mature answers of the former group.

Table 9. Girls' calendar age at moment of examination depending on early or late menarche

\begin{tabular}{lcccc}
\hline Menarche & $\bar{X}$ & $N$ & $S D$ & $p$ \\
\hline early & 18.51 & 133 & 0.34 & \\
late & 18.63 & 115 & 0.39 & $<0.01$ \\
\hline
\end{tabular}

Although menarche appeared really earlier in girls from families where mothers had higher education (Table 10), the used chi-square test showed that there were no relations between the content of 
the answers and the education level of the respondents' parents. Thus, the social position could not have influenced the obtained results.

Table 10. Girls' age of first menstruation in relation to their mothers' education level

\begin{tabular}{lcccc}
\hline Mother's education & $\bar{X}$ & $N$ & $S D$ & $p$ \\
\hline higher & 12.86 & 184 & 1.11 & \\
secondary school & 13.12 & 224 & 1.14 & $<0.05$ \\
vocational and & & & & \\
primary school & 13,21 & 42 & 1.03 & \\
\hline
\end{tabular}

The research also provided an opportunity to examine to what degree the menarche age depends on the factors affecting psyche. These relations were examined by HULANICKA [1986], SURBEY [1990], ŁUCZAK \& ŁASKAMIERZEJEWSKA [1990], MOFFIT et al. [1992]. The girls were asked how they evaluated their childhood. It appeared that few girls (only 21) who described their childhood as "unhappy" reached puberty 4 months earlier than those who described it as happy or normal. With those numbers the difference did not reach statistical significance (Table 11) but neither was it small, and besides, it was consistent with the results obtained by the authors mentioned above. The pubescence of those girls who admitted serious incidental experiences during childhood was also noted as slightly earlier (Table 12). These results comply with the authors' observations, mentioned above, of the stimulating influence of psychical stress on the puberty process.

Table 11. Age of menarche in girls with different childhood

\begin{tabular}{lccc}
\hline Childhood & $\bar{X}$ & $N$ & $S D$ \\
\hline happy & 13.04 & 273 & 1.13 \\
ordinary & 13.02 & 153 & 1.11 \\
miserable & 12.72 & 21 & 1.12 \\
\hline
\end{tabular}

Table 12. Serious personal experiences in childhood versus age of menarche

\begin{tabular}{lccc}
\hline $\begin{array}{l}\text { Serious experiences of } \\
\text { childhood }\end{array}$ & $\bar{X}$ & $\mathrm{~N}$ & $\mathrm{SD}$ \\
\hline yes & 12.87 & 121 & 1.17 \\
no & 13.09 & 266 & 1.11 \\
\hline
\end{tabular}

To sum up, the conducted analysis shows that the remaining characteristics related to psychical personality development of the questioned girls of 18-19 years of age does not show any significant, that is obvious, dependence on the age of sexual maturity. However, we observed certain tendencies which could prove a higher psychical maturity of the young women who entered puberty earlier than the others. Those who entered puberty earlier demonstrated, at the moment of research, greater degree of independence while choosing their future education (Tables 1,2) and greater responsibility for finding solutions in difficult situations (Table 4); this group included also girls who thought that self-improvement and upbringing were more important than hereditary factors in forming their personality (thus, showing greater responsibility for themselves, Table 6).

Self-estimation of psychical maturity in relation to peers appeared proportional to menarche age of the examined girls: the greater the self-attributed maturity, the longer the time period since the first menstruation (Table 7). We did not find the expected interdependence between the menarche age and the ability of expressing opinions controversial to those of the interlocutor (Table 5). The ability to initiate interpersonal relations appeared unexpectedly (insignificantly) higher in girls with late menarche (Table 3). Apart from that, observed earlier stimulating influence of psychical stress on the rate of puberty process was proved (Tables 11, 12). 


\section{Discussion}

There arises a question how one should interpret the obtained results. Are they credible enough to prove the lack of relation between the puberty age and the development of the majority of the investigated personality characteristics? Statistical insignificance of the investigated differences would account for such interpretation. Besides, it would remain in accordance with the observed diverse secular acceleration of physical and psychical development (mentioned in the introduction) and would favor the suggestion that factors responsible for the development acceleration find better breeding ground and quicker response in the physical sphere rather than psychical. This would also prove a (rather isolated) thesis of KOMOROWSKA [1963] that prematurely pubescent girls do not show psychical development different from their peers.

There are also some doubts, though, as to the above mentioned difficulties of methodological nature, that is the lack of an objective method allowing for univocal evaluation and comparison of psychical maturity degree of individuals. Psychological tests evaluating intelligence and school maturity have been used for a long time but there are still no maturity tests concerning other personality characteristics during puberty. Thus, out of necessity, we constructed a questionnaire, which would give at least an approximate evaluation of development levels of some personality characteristics with recognized development tendencies. However, for obvious reasons, the authors do not pretend to recognize this questionnaire as an ideal scientific instrument leading to arbitrary solutions, but only as a method al- lowing for possible distinction of tendencies indicating certain dependencies. Therefore, we approach our results with necessary reservations.

A weak point of our method is mainly the fact that it is based on the respondents' auto-presentation. In spite of the anonymity of questionnaires, the answers to direct questions might not have been entirely objective and honest. According to ZAZZO [1972] "The authors' image as compared to that of the others is characterized in girls (as well as in boys) by giving priority to their own aspirations and needs. Thus, the examined person sees himself mainly through his own intentions". It is obvious that the girls are reluctant to admit, even to themselves, their lack of independence in decisionmaking, inhibitions in interpersonal relations, feeling of inferiority, and inadequate preparation to "adult" life.

Apart from that, we have to take into consideration the fact that the auto-presentation factor is situationally intensified. Graduation is a period of verifying oneself and being verified, and the scientists were representatives of a higher education institution, which, for many girls, meant the longed-for aim at that moment. Hence the recognition of answer variants easily identified by the respondents as "correct" and "the best".

Thus, the used auto presentation undoubtedly caused the shifting of the answer distribution in the direction of answers favorable to personal image at the cost of the unfavorable ones. Since the latter were so few, they couldnot possibly reach the required level of statistical reliability concerning the obtained diverse menarche age. From among 450 girls only 15 admitted being psychically less mature in comparison to their peers, 
which explains why, in spite of the fact that this group entered puberty on the average almost half a year later that those of completely opposite self-estimation, the difference turned out statistically insignificant. Besides, another reason might have been the fact that the deficit of extremely "unfavorable" - in the respondents' opinion - answers led to the leveling of menarche age differences. Additionally, those unfavorable answers were - as we believe - directionally selected. The girls admitting being less mature might be recognized as more mature among the immature ones due to the very fact that they admitted it in the questionnaire. Thus, the methodological shortcomings mentioned above might have hidden, in effect, the investigated relations instead of highlighting them. Since we observed certain tendencies at all, we believe that they deserve recognition.

For this reason, we believe that even though the obtained results cannot univocally prove a distinct relation between the puberty age and the level of personality development reached at the age of 19 , yet we cannot negate such a relation, either. On the contrary, there is a distinct tendency towards immaturity with regard to the investigated personality characteristics in the late pubescent girls in comparison to those entering puberty earlier, suggesting that such a relation may exist. The conducted analysis shows that factors such as age and domestic-social environment did not play any decisive role. It appears that the early pubescent girls were not, at the moment of the experiment, older but even younger than the late pubescent ones, indicating that what determined the greater development of certain personality characteristics was not calendar age (neither can we exclude that it hindered, to a certain degree, their total disclosure). Also, an advantageous social status resulting from the mother's education level had no influence whatsoever, since we proved the lack of correlation between that last factor and the number of different answer variants.

It seems worth mentioning that similar experiments conducted 25 years ago by STRZYŻEWSKI [1974] on girls from Bydgoszcz gave similar "unclear" results, and yet they show similar tendencies, consistent with psychologists' opinion. Thus, it was proved that the earlier pubescent girls are, at the age of 14-15, taller and more corpulent than the late pubescent ones; they are also more intelligent and more mentally competent, more independent and self-sufficient, more active, resolute and better accepted by the peer group, that is generally socially better adapted. Also, the latest research by BODZSAR [1999] shows that Hungarian girls of 10-14 years of age reach higher intelligence and "creative originality" level when they are more advanced with regard to secondary sex character development (at this stage, however, there was no distinct differentiation dependent on social status). These results remain in accordance with psychologists' observations mentioned by HURLOCK [1985] demonstrating that the girls with delayed development of sex character show diffidence, exaggerated shyness, no ability of co-operation and lower sense of responsibility; they also obtain worse results at school and in intelligence tests, and their psycho-social maturity is low [BOMBA 1981]. The girls tall for their age are also characterized by worse social adaptation than those closer to standards [HURLOCK 1985]. 


\section{Final conclusions}

Further research is necessary to establish whether all the mentioned consequences of early or late puberty influence psyche of an individual entering adult life; it seems that the results presented here support that necessity. However, research methods should first be elaborated with psychologists allowing for objectivity by limiting the element of auto presentation through appropriate choice of questions asked "indirectly" which form the base of all tests. If the co-operation and further research are successful, they will hopefully lead to proving the observed tendencies as not incidental but resulting from the actually existing regularities.

\section{References}

Allport G.W., 1970, Structure et developpement de la personalite. Delachaux et Niestle, Neuchatel

BADURA-MADEJ W., 1980, Zagadnienie rozwoju w psychologii, [in:] Zaburzenia psychiczne u młodzieży, M. Orwid (ed.), PZWL, Warszawa, pp. 13-37

BoDzSAR E.B., 1999, Some psychosocial aspects of puberty, IV-th International Anthropological Congress of Ales Hrdlicka, Prague and Humpolec (31.08-4.09.1999), Abstracts, p. 17

BomBA J., 1981, Biologiczne problemy okresu dojrzewania i ich psychiczne nastęstwa, [in:] Zaburzenia psychiczne u młodzieży, M. Orwid (ed.), PZWL, Warszawa, pp. 38-53

ChŁOPKIEWICZ M., 1987, Osobowość dzieci i młodzieży, rozwój $i$ patologia, Wyd. Szkol. i Pedag., Warszawa, pp. 139-143

GADAMSKa T., K. ZmysŁowsKa, Z. GAJewsKAZBIEGIEŃ, 1997, Wybrane aspekty rozwoju psychicznego u młodzieży, Medycyna Wieku Rozwojowego, 1, 191-205

HulanicKa B., 1986, O wptywie czynników psychicznych na dojrzewanie, Mat. i Prace Antr., 107, 45-80
Hurlock E.B., 1965, Rozwój młodzieży, PWN, Warszawa

HuRlock E.B., 1985, Rozwój dziecka, PWN, Warszawa

ILG F.L., L.B. AMES, S.M. BAKER, 1998, Rozwój psychiczny dziecka, cz. 2, Gdańskie Wyd. Psychol., Gdańsk

JACZEWSKI A., 1995, Biologiczne $i$ medyczne podstawy rozwoju $i$ wychowania, Wyd. Szkol. i Pedag., Warszawa

JaCzewski A., B. Woynarowska, 1982, Dojrzewanie, Wyd. Szkol. i Pedag., Warszawa

KomorowsKa M., 1963, Z zakresu pokwitania dziewczat, PZWL, Warszawa

ŁuCZAK E., 1994, Poziom rozwoju fizycznego dzieci $\mathrm{z}$ trudnościami szkolnymi, Szkoła Specjalna, 1, 17-29

ŁUCZAK E., T. ŁASKA-MiERZEJEWSKA, 1990, Rozwój fizyczny $i$ stan zdrowia dzieci $z$ rodzin alkoholicznych, Problemy Opiekuńczo-Wychow., 9, 140-143

Moffit T.E., A. Caspi, J. Belsky, P.A. Silva, 1992, Childhood experience and the onset of menarche. A test of sociobiological model, Child Development, 63, 47-58

OBuchowsKa I., 1983, Okres dorastania, Inst. Wyd. „Nasza Ksiegarnia”, Warszawa

OBuCHOWSKa I., 1996, Drogi dorastania i psychologia rozwojowa okresu dorastania dla rodziców $i$ wychowawców, Wyd. Szkol. i Pedag., Warszawa

OBuCHOwSKi K., 1972, Psychologia dażeń ludzkich, PWN, Warszawa

REYKOWSKI J., 1977, O rozwoju osobowości, Studia Filozoficzne, 7, 49-63

RóżYCKA J., 1968, Badania nad wspótzależnościa między rozwojem umysłowym a fizycznym dzieci, Ossolineum, Wrocław

SMOLEŃSKA Z.M., G. WIECZORKOWSKA, 1993, Kryteria wartościowania u młodzieży warszawskiej w latach 1985-1990, Psychol. Wychowawcza, 2, 122-132

SPIONEK H., 1973, Zaburzenia rozwoju uczniów a niepowodzenia szkolne, $\mathrm{PWN}$, Warszawa

STRZYŻEWSKI S., 1974, Tempo dojrzewania biologicznego a niektóre cechy osobowości dziewczat $w$ wieku dorastania, Roczniki Naukowe AWF Katowice, 3

SURBEY M.K., 1990, Family composition, stress and the timing of human menarche, [in:] Socioendocrinology of Primate Reproduction, 
T.E. Ziegler \& F.B. Bercovitch (eds.), WileyLiss, New York, pp. 11-32

WIŚNIEWSKI C., 1998, Kształtowanie osobowości. Edukacja i Dialog, 34, 16-20

ZAzzo B., 1972, Oblicza młodości - psychologia różnicowa wieku dorastania, PWN, Warszawa

ZDUNKIEWICZ L., 1970, Niektóre aspekty biologiczne uwarunkowań postępów szkolnych uczniów szkót podstawowych, Krajowy Zjazd
Medycyny i Higieny Szkolnej, Warszawa, Abstracts, 15-16

ŻEBrowska M., 1986, Psychologia rozwojowa dzieci i młodzieży, PWN, Warszawa

ŻUKOWSKI R., 1966, Badania nad rozwojem fizycznym, sprawnościq fizycznq i sprawnościq umystowa młodzieży szkót podstawowych Warszawy, Roczniki Naukowe AWF, Warszawa, 6, 233-260

\section{Streszczenie}

Z literatury dotyczącej psychologii wieku rozwojowego wynika, że wyprzedzenie bądź opóźnienie w dojrzewaniu płciowym może pociagać za sobą określone konsekwencje psychiczne, trudne do przezwyciężenia, $\mathrm{z}$ tendencją raczej do trwania niż zanikania, a niekiedy ulegające pogłębieniu. Przyczynia się do tego traktowanie dziecka przez dorosłych raczej zgodnie z jego wyglądem niż z wiekiem kalendarzowym. Według różnych autorów obserwujących młodzież do lat $15, \mathrm{z}$ opóźnionym dojrzewaniem wiąże się m.in. większa nieśmiałość, mniejsza samodzielność, niższe poczucie odpowiedzialności, gorsza sprawność umysłowa i ogólnie gorsze przystosowanie społeczne.

Celem naszych badań było uzyskanie odpowiedzi na pytanie, czy poziom dojrzałości psychicznej stwierdzany u progu dorosłości wykazuje jakikolwiek zwiazek z czasem, w którym dziewczęta osiagnęly dojrzałość płciową. Zbadano 450 uczennic klas maturalnych w wieku 18-19 lat, stosując metodę ankietową. Zastosowane pytania miały służyć ustaleniu:

- stopnia zdecydowania co do projektów dalszej edukacji (tab. 1) oraz stopnia samodzielności w dokonywaniu wyborów (tab. 2 i 4);

- umiejętności nawiązywania kontaktów z innymi (miernik przystosowania społecznego) (tab. 3);

- stopnia trudności w wypowiadaniu własnej opinii, kontrowersyjnej w stosunku do rozmówcy (odrzucenie zewnątrz sterowania, rozwój indywidualności) (tab. 5);

- odpowiedzialności za kształtowanie własnej osobowości (tab. 6);

- samooceny dojrzałości psychicznej na tle rówieśnic (tab. 7);

- czy badana aktualnie pali papierosy (jako miernik rozwagi) (tab. 8).

Drogą wywiadu ustalano retrospektywnie wiek menarche.

Zastosowane kryterium chi-kwadrat wykazało brak istotnego statystycznie związku pomiędzy różnymi wariantami odpowiedzi udzielanych na zadane pytania a czasem pokwitania ankietowanych dziewcząt wyrażonym w trzech kategoriach wieku menarche (wczesnego - przed 12 r. życia, późnego - po 14 r. życia oraz pośredniego). Porównanie średnich arytmetycznych wieku menarche dziewcząt $\mathrm{w}$ zależności od wybranych przez nie odpowiedzi również nie wykazało istotnych różnic, jednak zarysowały się pewne tendencje, na ogół zgodne z oczekiwaniem psychologa. Nieco wcześniej dojrzewały te uczennice, które w momencie badania wykazywały większy stopień zdecydowania i samodzielności w wyborze kierunku studiów, większą łatwość $\mathrm{w}$ wyborze drogi wyjścia $\mathrm{z}$ trudnych sytuacji, a także te dziewczęta, które pracę nad sobą i wychowanie przez rodziców uznały za czynnik ważniejszy w kształtowaniu własnej osobowości od czynnika dziedzicznego. Ocena własnej dojrzałości psychicznej okazała się proporcjonalna do czasu, jaki upłynął od wystapienia pierwszej menstruacji. Dziewczęta palące papierosy dojrzewały później od niepalących. A więc w tych cechach, które 
świadczą o większym zaawansowaniu rozwoju osobowości wystapiła tendencja do wcześniejszego pokwitania. Nie stwierdzono natomiast takiej tendencji, która wskazywałaby na zależność pomiędzy wiekiem pokwitania a umiejętnością nawiązywania kontaktów z innymi ani też przeciwstawiania im własnych sądów.

Badania stanowiły okazję do potwierdzenia, zauważonego wcześniej przez innych autorów, stymulującego wpływu stresów psychicznych na tempo pokwitania. Wcześniej dojrzewały te badane przez nas dziewczęta, które określały ogólnie swoje dzieciństwo jako nieudane oraz te, które zanotowały w pamięci poważne incydentalne przeżycia w okresie dzieciństwa (tab. 9 i 10).

Uważamy, że brak istotności w obserwowanych różnicach nie upoważnia nas jeszcze do zdecydowanego stwierdzenia, iż poziom rozwoju cech osobowości po 18 roku życia jest niezależny od czasu osiągniętej dojrzałości fizjologicznej. Przeszkodę stanowi niewattpliwie element autoprezentacji w zastosowanej ankiecie. Pytania zadawane wprost sprawiły, że liczba respondentek wybierających odpowiedzi klasyfikujące je jako mniej dojrzałe psychicznie okazała się bardzo ograniczona (prawdopodobnie głównie na rzecz kategorii pośredniej), co nie pozwoliło na osiagnięcie progu istotności w stosowanych porównaniach wieku menarche, a ponadto spowodowało pewne „spłaszczenie" różnic. Przeprowadzona próba ujawniła dotkliwy brak dostatecznie jednoznacznych i obiektywnych mierników poziomu dojrzałości, jakimi dysponuje psychologia dla tak zwanego ,wieku dorastania" (podczas gdy posiada takowe dla określania na przykład dojrzałości szkolnej czy poziomu inteligencji). Zauważone tendencje zasługują jednak naszym zdaniem na uwagę, skoro ujawniły się pomimo tego w sposób dość konsekwentny i zgodny z oczekiwaniem. Autorki postulują więc potrzebę współpracy z psychologami w kierunku wypracowania możliwie obiektywnej metody ograniczającej do minimum element autoprezentacji, co pozwoli, być może, na rozwinięcie badań w tej mało poznanej, jak dotąd, problematyce. 